\title{
Comparative nesting success of the keyhole mud-dauber (Hymenoptera, Crabronidae, Trypoxylon nitidum) in different substrates
}

\author{
Dyan M. Nelson ${ }^{1,2}$, Christopher K. Starr ${ }^{1}$ \\ I Dep't of Life Sciences, University of the West Indies, St Augustine, Trinidad \& Tobago 2 PCS Nitrogen Trinidad \\ Ltd, Atlantic Avenue, Point Lisas, Trinidad \& Tobago \\ Corresponding author: Christopher K. Starr (ckstarr@gmail.com)
}

Academic editor: M. Obl | Received 25 July 2016 | Accepted 13 September 2016 | Published 28 August 2016

http://zoobank.org/24C95964-7029-40C1-AE67-9121D2B4D823

Citation: Nelson DM, Starr CK (2016) Comparative nesting success of the keyhole mud-dauber (Hymenoptera, Crabronidae, Trypoxylon nitidum) in different substrates. Journal of Hymenoptera Research 52: 163-167. doi: 10.3897/ jhr.52.9997

\begin{abstract}
The solitary wasp Trypoxylon nitidum F. Smith nests in a variety of existing cavities. Nesting success - the fraction of completed, provisioned cells that produced adult offspring - can be estimated by examination of old cells. We estimated nesting success of T. nitidum in new and old (previously utilized by $T$. nitidum) bamboo traps nests, old nests of solitary wasps (Sceliphron fistularium (Dahlbom), Trypoxylon albitarse Fabr. and Zeta argillaceum (L.)) and social wasps (Polistes lanio (Fabr.) and P. versicolor (Olivier)) in Trinidad, West Indies. Success was markedly higher (61.4\%) in new trap nests and significantly lower $(5.6 \%)$ in old trap nests than in other substrates. Mean success in old nests of other wasps varied from $10.0 \%$ to $28.8 \%$, with no general difference between those of solitary and social wasps. We infer that a) rented (reutilized) nests are more easily located by parasites than are new trap nests, and b) old trap nests have a higher load of parasites and disease organisms than substrates not previously utilized by T. nitidum.
\end{abstract}

\section{Keywords}

Nesting success, Polistes lanio, Polistes versicolor, Sceliphron fistularium, Trypoxylon albipes, Zeta argillaceum 


\section{Introduction}

Trypoxylon Latr., 1796 (Hymenoptera: Crabronidae) is a worldwide genus of more than 300 known species of spider-hunting wasps (Bohart and Menke 1976). All studied species mass provision with paralyzed spiders. Some species build free-standing mud nests, while others nest in pre-existing cavities. Many of these latter will accept artificial tubular cavities known as trap nests (Medler 1967, Griswold and Coville 1986).

The keyhole mud-dauber, Trypoxylon (Trypargilum) nitidum F. Smith, is common about houses in Trinidad, West Indies. It constructs no free-standing nest but utilizes various existing cavities, which it divides with mud partitions into a linear series of cells (Richards 1934: 347). Cavities include such human-made structures as nail holes, keyholes and book backs, as well as old nests of various solitary and social wasps. When a cell is fully provisioned with spiders, the female lays an egg, seals the cell with mud, and has no further contact with the cell. The cocoon is dark brown, hard and brittle, more or less cylindrical, with the front end round and slightly swollen.

Provision of sufficient food does not guarantee that the larva will develop to adulthood. Brood and their provisions attract a variety of parasites, parasitoids and pathogens. Nesting success is the fraction of fully provisioned, closed cells that give rise to mature offspring. In the one review of the subject to date, Weaving (1995) reported figures from about 50 solitary-wasp species in various parts of the world. These are mostly between $45-75 \%$, although figures below $30 \%$ or above $90 \%$ are not rare. Among the wasps treated are five Trypoxylon species, with nesting success between 5676\%. Tormos et al. (2005) and Musicante and Salvo (2010) give figures of $45-87 \%$ for a further six species with nesting habits similar to those of T. nitidum.

As a rule, nesting success of mud-nesting solitary wasps can be estimated with considerable confidence by examining old cells. In the case of $T$. nitidum, emerging adults leave a distinctive emergence hole. This proffers the opportunity to compare success rates in the various types of nest substrates. In this paper we test the hypothesis that choice of a nest substrate is a significant factor in nesting success.

\section{Materials and methods}

The main part of this study was carried out in the St Augustine area of Trinidad, West Indies during September-November 1999, with some auxiliary study in later years. Our material comprised 2620 T. nitidum cells from 288 nests.

Nest sites were of three types. We made trap nests from bamboo stems of 5-11 mm inner diameter, each about $30 \mathrm{~cm}$ long. These were split longitudinally, plugged midway along their length with tissue paper, resealed and placed in sheltered areas on buildings that T. nitidum was known to frequent. Many of these trap nests were reconstituted after they had been utilized by T. nitidum and were set out again the following year.

The second type comprised old nests of the mud-nesting solitary wasps Sceliphron fistularium (Dahlbom) (Sphecidae), Trypoxylon (Trypargilum) albitarse Fabr. (Cra- 


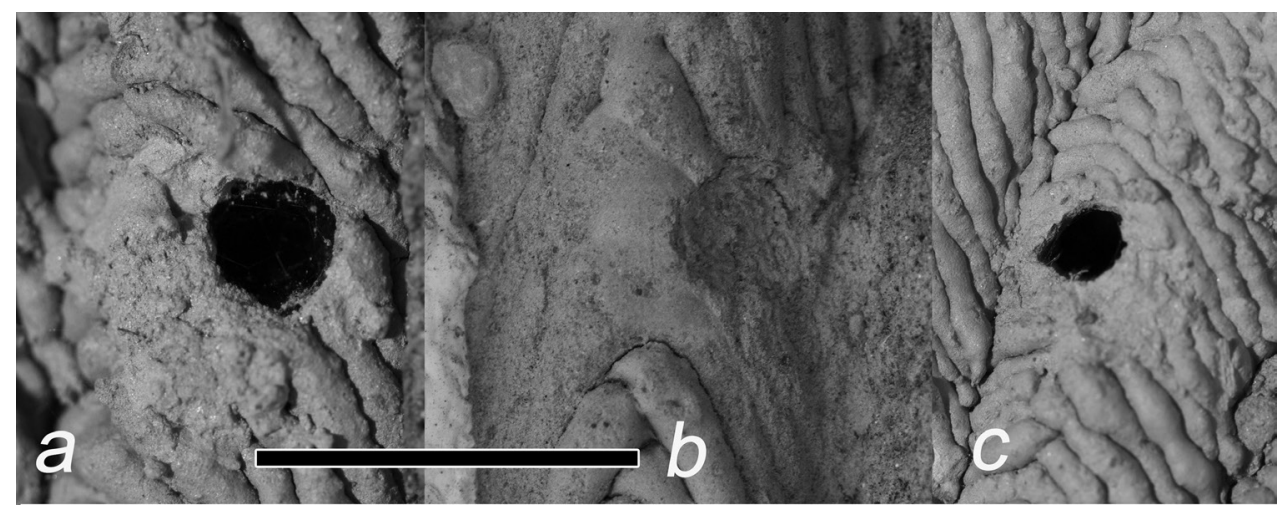

Figure I. Stages in the reutilization of old Trypoxylon albitarse cells by T. nitidum. a Without reutilization (note $T$. albitarse emergence hole) b Reutilized with no emergence by $T$. nitidum (note closure without emergence hole) $\mathbf{c}$ Reutilized with emergence by $T$. nitidum (note smaller emergence hole). Scale bar $=1 \mathrm{~cm}$. Figure by Terry Sampson.

bronidae) and Zeta argillaceum (Linn.) (Vespidae: Eumeninae). T. albitarse is much larger than T. nitidum and constructs free-standing nests (Fig. 1). The third type was old nests of the common social wasps Polistes lanio (Fabr.) and P. versicolor (Olivier) (Vespidae: Polistinae). These open combs of uniform paper cells are presumably a very convenient substrate for T. nitidum.

We opened and examined T. albitarse and Z. argillaceum nests in-situ. All other substrate types were brought into the laboratory. The fate of $T$. nitidum brood could be inferred by searching the nest exterior and cell contents for such evidence as emergence holes, empty pupal cases, dead pupae, frass and exuviae of parasitic organisms. The effects of parasites and parasitoids are often evident long after the fact from their signature exit holes. Emergence holes of T. nitidum in cells of the other mud-nesting wasps are consistently smaller (about $4 \mathrm{~mm}$ diameter) than those of the original builders $(5-7 \mathrm{~mm})$. Where a $T$. nitidum cell had failed in one of these other mud nests, this was evident externally by a species-characteristic mud closure to the host cell.

\section{Results}

T. nitidum utilized 103 new traps nests, accepting none with an inner diameter greater than $10 \mathrm{~mm}$. Those with inner diameter of $6 \mathrm{~mm}$ were utilized with the greatest frequency. Brood cells had a mean length of $13 \mathrm{~mm}$, intercalary cells a mean length of 16 $\mathrm{mm}$, and vestibular cells a mean length of $17 \mathrm{~mm}$.

Table 1 shows nesting success of $T$. nitidum in seven different substrates. There were significant differences among substrates (Table 2). We identify four groups of substrates, in increasing order of nesting success: a) old trap nests, b) old nests of $S$. fistularium, c) old nests of other wasps, and d) new trap nests. 
Table I. Nesting success of Trypoxylon nitidum in different substrates. In new trap nests, the number of successes is estimated from the number of known successes (349) and the projected fate of 80 live pupae, as explained in the text. In all other substrates, the number of successes is directly known. Old trap nests are those that were previously utilized by $T$. nitidum.

\begin{tabular}{l|c|c|c|c}
\hline \multicolumn{1}{c|}{ Substrate nest } & Total nests & Total cells & Number of successes & Success rate (\%) \\
\hline New trap nests & 103 & 675 & 415 & 61.4 \\
\hline Old trap nests & 92 & 502 & 28 & 5.6 \\
\hline Sceliphron fistularium & 35 & 159 & 16 & 10.0 \\
\hline Trypoxylon albitarse & 21 & 76 & 15 & 28.8 \\
\hline Zeta argillaceum & 12 & 45 & 11 & 24.4 \\
\hline Polistes lanio & 31 & 808 & 149 & 18.4 \\
\hline Polistes versicolor & 16 & 361 & 78 & 21.6 \\
\hline \multicolumn{1}{c}{ Total } & 288 & 2626 & 712 & \\
\hline
\end{tabular}

Table 2. Differences in nesting success of Trypoxylon nitidum among different substrates, based on Table1. Results of Fisher's exact test of successes and failures among pairs of substrates, based on Table 1 . NS, $\mathrm{p}>0.05 .{ }^{*}, \mathrm{p}<0.05 .{ }^{* *}, \mathrm{p}<0.01$.

\begin{tabular}{l|c|c|c|c|c|c}
\hline & $\begin{array}{c}\text { old trap } \\
\text { nests }\end{array}$ & $\begin{array}{c}\text { Sceliphron } \\
\text { fistularium }\end{array}$ & $\begin{array}{c}\text { Trypoxylon } \\
\text { albitarse }\end{array}$ & $\begin{array}{c}\text { Zeta } \\
\text { argillaceum }\end{array}$ & $\begin{array}{c}\text { Polistes } \\
\text { lanio }\end{array}$ & $\begin{array}{c}\text { Polistes } \\
\text { versicolor }\end{array}$ \\
\hline new trap nests & $* *$ & $* *$ & $* *$ & $* *$ & $* *$ & $* *$ \\
\hline old trap nests & & $*$ & $* *$ & $* *$ & $* *$ & $* *$ \\
\hline Sceliphron fistularium & & & $*$ & $*$ & $*$ & $* *$ \\
\hline Trypoxylon albitarse & & & & NS & NS & NS \\
\hline Zeta argillaceum & & & & & NS & NS \\
\hline Polistes lanio & & & & & & $*$ \\
\hline
\end{tabular}

\section{Discussion}

The results corroborate the hypothesis that type of nest substrate affects nesting success. The observed variation among substrates - from 10.0 to $61.4 \%$ - is mostly within the range reported in the literature for other solitary wasps and bees. New bamboo trap nests give rise to much greater success than any other substrate, while old trap nests give much lower success. Success in the intermediate group - old nests of solitary and social wasps - shows no striking differences or pattern of variation. In particular, the solitary (mud-nesting) and social (paper-nesting) species do not separate as distinct groups. The presumed greater ease with which parasites can penetrate thin paper cell walls than thicker mud walls does not produce the expected lower nesting success in the former.

Given the clear superiority of virgin substrates, why does $T$. nitidum often reutilize old nests of other wasps? There is almost certainly a trade-off between these two types of substrates. Old nests of some wasps are presumably easy to find and provide ready-made cavities that require very little modification. By searching under the eaves of buildings (as we did), a female may within minutes find an old Polistes nest with enough cells for her lifetime reproduction. Substrate-search time is probably a major 
factor in the number of cells she can provision. However, this kind of substrate is presumably relatively easy for nest parasites to find. Similarly, Wcislo (1996) concluded from a comparison of nesting success in a broad range of wasps and bees that the clustering of trap nests into bundles facilitates the discovery by parasites of several nests at once. For this reason and because they would seem relatively easy for parasites to penetrate, nesting success in old Polistes nests (around 20\%) seems surprisingly high.

Utilization of old trap nests, in contrast, appears to be a very poor choice with no evident trade-off. This may be due to residual disease organisms from the previous season and/or residual odour of $T$. nitidum to which parasites can orient.

The very low nesting success in old $S$. fistularium nests is puzzling. This solitary wasp builds thick-walled nests that are presumably hard for any nest parasite to penetrate. Possible explanations include a) brood failure due not to nest parasites but to fungi and other pathogens, which may do better in a denser, moister nest, and b) penetration of cells before they are closed, so that nest-wall thickness is not a factor.

\section{Acknowledgements}

We thank Alan Weaving for criticism of an earlier version, Bruce Lauckner for statistical advice and Terry Sampson for Fig. 1.

\section{References}

Bohart RM, Menke AS (1976) Sphecid Wasps of the World: A Generic Revision. Univ. California Press, Berkeley, 695 pp.

Griswold C, Coville RE (1986) Observations on the prey and nesting biology of spider-hunting wasps of the genus Trypoxylon (Hymenoptera: Sphecidae). Proceedings of the Ninth International Congress of Arachnology, Panama 1983: 113-116.

Medler JT (1967) Biology of Trypoxylon in trap nests in Wisconsin (Hymenoptera: Sphecidae: Trypoxylinae). American Midland Naturalist 78: 344-358. doi: 10.2307/2485235

Musicante ML, Salvo A (2010) Nesting biology of four species of Trypoxylon (Trypargilum) (Hymenoptera: Crabronidae) in Chaco Serrano woodland, Central Argentina. Revista de Biología Tropical 58: 1177-1188. http://www.scielo.sa.cr/pdf/rbt/v58n4/a11v58n4.pdf Richards OW (1934) The American species of the genus Trypoxylon. Transactions of the Royal Entomological Society of London 82: 173-360. doi: 10.1111/j.1365-2311.1934.tb00033.x

Tormos J, Asís JD, Gayubo SF, Calvo J, Martín MA (2005) Ecology of crabronid wasps found in trap nests from Spain (Hymenoptera: Spheciformes). Florida Entomologist 88: 278284. doi: 10.1653/0015-4040(2005)088[0278:eocwfi]2.0.co;2

Wcislo WT (1996) Parasitism rates in relation to nest site in bees and wasps (Hymenoptera: Apoidea). Journal of Insect Behavior 9: 643-656. doi: 10.1007/BF02213885

Weaving AJS (1995) A comparison of nesting success and nesting habits in some Afrotropical aculeate wasps, with particular reference to nest parasites (Hymenoptera: Sphecidae, Eumenidae). Annnals of the Cape Province Museum (Natural History) 19: 181-224. 